\title{
Spurring Economic Growth in Terms of Happiness, Human Development, Competitiveness, and Global Innovation: The ASEAN Case
}

\author{
Saida Zainurossalamia ZA ${ }^{1}$, Siti Amalia ${ }^{2, *}$, Dio Caisar Darma $^{3}$, and Musdalifah Azis ${ }^{1}$ \\ ${ }^{1}$ Department of Management, Faculty of Economics and Business, Mulawarman University, Jl. Tanah Grogot No. 1, Gn. Kelua, \\ Samarinda 75117, Indonesia \\ ${ }^{2}$ Department of Economics, Faculty of Economics and Business, Mulawarman University, Jl. Tanah Grogot No. 1, Gn. Kelua, Samarinda \\ 75117, Indonesia \\ ${ }^{3}$ Department of Management, Sekolah Tinggi Ilmu Ekonomi Samarinda, Jl. K. H. Abul Hasan No. 77, Pasar Pagi, Samarinda 75242, \\ Indonesia \\ *Corresponding author: siti.amalia@feb.unmul.ac.id
}

\section{KEYWORDS \\ ASEAN}

Human resources

Long-term

Productivity

Sustainable economics

SUBMITTED 25 October 2020

REVISED 12 March 2021

ACCEPTED 20 March 2021

\begin{abstract}
Happiness, human development, level of competitiveness, and capacity in innovation all play an important role in spurring long-term sustainable economic growth. This study presents the relationship between these factors-happiness, human development, competitiveness, and innovation in the ASEAN region-in how they influence economic growth. To date, there has been a lack of research on this specific issue, and thus it is an interesting and little-known one to study. Panel data were used comprising a combination of time series and cross-sections. The object of the study was ASEAN member countries using the multiple linear regression method. For the years of 2013-2019, we found that overall economic growth had a real impact. The results showed that human development and global innovation are two-way related to economic growth (positive and significant). Conversely, there was an insignificant influence of happiness and competitiveness on economic growth. Competitiveness, in particular, can reduce the level of economic growth. The policy considerations pursued by countries in ASEAN are through the respective governments' strategic steps to improve the productivity of their populations, because human resources are needed not only as objects but actors in economic activities themselves in managing development.
\end{abstract}

(c) The Author(s) 2021. This article is distributed under a Creative Commons Attribution-ShareAlike 4.0 International license.

\section{INTRODUCTION}

Economic growth to date has become an important reference in seeing the extent of its economic patterns and the level of public welfare. Because of its importance, countries are competing to increase the value of economic growth, with various measures and strategies implemented. For this reason, economic growth is one of the vital indicators that include the production process, distribution, and consumption of goods and services. All of these require the roles of human development, competitiveness, innovation, and level of happiness, which ideally are aligned with the desired goals (Wijaya et al. 2021).

Many countries with low incomes promote economic growth because it is often seen as a success and policy priority-as something that looks important, because the goal is to increase one's happiness (Easterlin 2012). Those who live in certain countries (for example developed countries) see that material wealth is not the only measure of happiness. Many individuals have found financial wealth and assets to not fully make their happiness. At the same time, the need for a sense of happiness sometimes arises from social and environmental aspects (Loke et al. 2014).

Humans who serve as actors in development always create their own innovations and creativity. Therefore, eco- nomic growth will not be created, if it is not supported by the equitable development of resources. A commitment to spur economic growth would do well to involve human development. In enhancing human development, it must be consistent, so that economic growth increases, in order to create sustainable integration (Appiah et al. 2019).

In addition, national competitiveness is considered as one of the main factors for developed and developing countries. The government, as a policymaker, specifically responds to the importance of the competitiveness of its citizens. Some observers and experts in the field of economics have highlighted the competitiveness and other matters relating to the competitive or non-competitive problems of a country (Lall 2001; Kordalska and Olczyk 2016).

Countries that are classified as "developing," such as those in the ASEAN region, need encouragement to stimulate good innovations that contribute to elevated human productivity in supporting quality economic growth. This is very much needed, bearing in mind that ASEAN countries continue to compete with countries that are classified as advanced in terms of natural resource management. For developing countries, they must focus on the inclusion of policies on innovation in their national strategies, in order to ensure its impact on economic growth (Darma 2019; AlZaroog and Baqir 2020). 
The contributions of this study are expected to be material for consideration and reference by academics, practitioners, and the government in addressing the problems that have been presented previously. The sharpness of this study focuses on several factors that influence economic growth in ASEAN, where these factors are only limited to happiness, human development, competitiveness, and global innovation. These contributions can additionally provide added value in the ASEAN region to highlight the dynamics related to economic growth, which are not always measured from the monetary and fiscal aspects, but also the role of human resource productivity in response to the demographic bonus.

\section{MATERIALS AND METHODS}

\subsection{Theoretical background and hypothesis}

In rich, developing and transition countries, it has been proven that with high economic growth, it can increase life satisfaction. Through the acceleration of the rate of economic growth, quality is not necessarily able to increase life satisfaction in the long run. The existence of cultural, social and political differences in each country at least makes the perception of the value of economic growth very varied. For example, happiness in the United States has increased from year to year and brought great changes to economic growth (Easterlin 2012).

Indeed, so far there is a fairly strong relationship between GDP per capita and happiness. The importance of GDP growth in raising living standards and creating new jobs will bring happiness closer. However, this is only seen in the aspect of economic development. In fact, there are also other indicators of welfare that are not economical (Esmail and Shili 2018).

Increasing economic growth will provide employment in the long run, and consequently have an impact on per capita income. Indirectly, it will play an important role in community welfare and expand government capacity to improve the quality of human resources through the provision of health, access to health, and infrastructure. In turn, harmony will be created in the future in human development with high productivity (Mukherjee and Chakraborty 2010).

Several studies have shown that there is a two-way relationship between human development and economic growth. This implies that a country that has good human resource capacity will form inclusive economic growth, whereas if human development is still low, it will not support economic growth (or even tends to be negative). This reality has been addressed by countries implementing massive human resource management. In other words, the relationship between these two indicators is like a cycle (Ranis et al. 2000; Costantini and Monni 2008; Ghosh 2006).

The main concern in developed and developing countries is that policymakers in particular are racing to advance national competitiveness and enhance it with various strategies (Rusu and Roman 2018). Competitiveness has become part of assessing the ability of companies, industries, regions, and nations to produce competition at the global level. With relatively high income and sustainable employment, it can generate added value. This needs to be highlighted, in that the competitiveness of a country refers to its economic structure and institutions that aid in its economic growth as a weight at the global level (Hatzichronoglou 1996; Porter et al. 2000).
Furthermore, innovation is fundamental to economic development. It is needed in competition, not only from companies but from industries and countries, as well. Consequently, in order to achieve high levels of production and distribution (goods and services), innovation is necessary (Cheung 2014).

Both the relationship between innovation and economic growth have received great attention from researchers. Schumpeter described the model of economic growth by looking at the competition through innovation and the importance of educational factors in driving economic growth. The link between innovation and economic growth now refers to developed and developing countries to increase broad markets (Carlin 1956; Aghion et al. 2002; Pece et al. 2015).

The gap between theoretical insight and practical problematics has raised major concerns. The vital justification for theoretical will, ideally, hopes that economic growth will increase due to the drive for competitiveness, happiness, human development, and global innovation. However, in reality, studies relevant to this concept are inversely proportional to what is happening in developing regions such as ASEAN. Case studies in developed countries, of course, are not comparable to countries that tend to apply "conventional" economic systems based on primary or capitalintensive economic structures, so that it is very different from those who rely more on sectors whose direction is in the service sector. Figure 1 concentrates on the extent to which support for economic growth is seen from the sides that have not been highlighted by previous researchers. It is interesting to combine concepts such as happiness, human development, competitiveness, and global innovation together in order to spur economic growth. From here, it also can be identified that these four items are independent variables, while economic growth is demonstrated as the dependent variable. The dependent variable is the group or object that is influenced by the independent variable and the proportion of the independent variable functions to influence the dependent variable (e.g. Flannelly et al. 2014; Wierenga and van Bruggen 1998).

From several literature studies and previous studies, we arranged the following hypotheses:

- Hypothesis-1: There is a positive and significant relationship between happiness and economic growth.

- Hypothesis-2: There is a positive and significant relationship between human development and economic growth.

- Hypothesis-3: There is a positive and significant relationship between competitiveness and economic growth.

- Hypothesis-4: There is a positive and significant relationship between global innovation and economic growth.

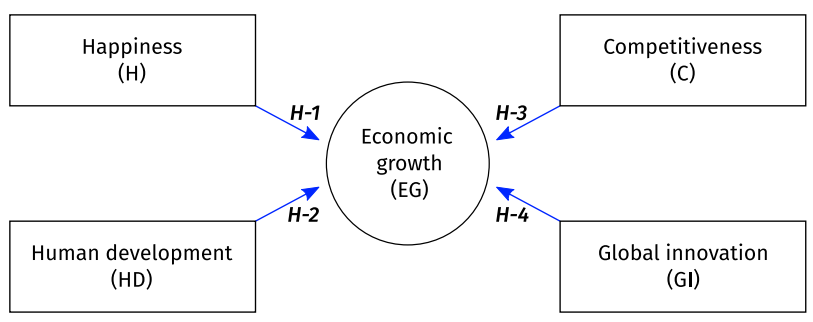

FIGURE 1. Study framework. 
TABLE 1. Component measurements.

\begin{tabular}{|c|c|c|c|}
\hline Variable (code) & Scale & Explanation & Source \\
\hline Economic growth (EG) & Percentage (\%) & $\begin{array}{l}\text { An output that contains the accumulation of production, distribution, } \\
\text { and consumption activities in a country in a certain period. }\end{array}$ & The Global Economy (2020) \\
\hline Happiness $(\mathrm{H})$ & Index (13-19) & $\begin{array}{l}\text { Living conditions that include dimensions of life satisfaction, } \\
\text { dimensions of feelings, and dimensions of the meaning of life of the } \\
\text { population. }\end{array}$ & The Global Economy (2020) \\
\hline Human development (HD) & Index (0-1) & $\begin{array}{l}\text { Measures for achieving human development are based on many basic } \\
\text { components of quality of life. }\end{array}$ & The Global Economy (2020) \\
\hline Competitiveness (C) & Index (1-7) & $\begin{array}{l}\text { The ability of countries to provide high levels of prosperity to their } \\
\text { population. }\end{array}$ & The Global Economy (2020) \\
\hline Global innovation (GI) & Index $(0-100)$ & An assessment of the country's capacity and success in innovation. & The Global Economy (2020) \\
\hline
\end{tabular}

\subsection{Reseach model}

To facilitate the understanding of this study, explanations relating to operational variables are required. Variable definitions consequently need to be specified, in order to avoid double interpretations, and that the use of predetermined variables is limited (Table 1).

The object of the study was the countries that are members of ASEAN (Philippines, Indonesia, Malaysia, Singapore, Thailand, Brunei Darussalam, Vietnam, Laos, Myanmar, and Cambodia). Panel data-based data were employed to assess the relationship between the variables of happiness, human development, competitiveness, and innovation on economic growth in the ASEAN countries. Study data comprised a total of seven years (2013-2019).

The primary reason for using panel data is because studies refer to data that contains observations of time series from some individuals. Therefore, observations in panel data involve at least two dimensions (namely crosssectional and time series). In addition, another superiority of the panel data is that it can compare several study objects; for example, between a group or organization, company, region, or country (Hsiao 2005).

We applied a multiple linear regression model to answer the intended purpose. Regression assumptions as analytical tools that match the relationship between one or more to minimize the number of quadratic errors. This model is very suitable because it reveals the difference between the actual and predicted values of the outcome variable (Zdaniuk 2014). The detailed formulas of the variables' linear relations are shown in Equations 1 and 2.

$$
Y_{i t}=\alpha+\beta^{*} X_{i t}+n+\varepsilon_{i t}
$$

Equation 1 is a basic function in regression, so it needs to be adjusted to the statistical functions below (Equation 2):

$$
E G_{i t}=\alpha+\beta_{1} H_{i t}+\beta_{2} H D_{i t}+\beta_{3} C_{i t}+\beta_{4} G I_{i t}+\varepsilon_{i t}
$$

where: $i$ (observation), $t$ (time), it (number of panel data of 2013-2019), $Y$ (economic growth), $\alpha$ (constant), $\beta_{1}$ (coefficient of happiness), $\beta_{2}$ (coefficient of human development), $\beta_{3}$ (coefficient of competitiveness), $\beta_{4}$ (coefficient of global innovation), and $\varepsilon$ (error term).

\section{RESULTS AND DISCUSSION}

In the statistical calculations, each factor was assessed with several tests via the regression model, classical assumptions, and the displayed data during the observation period. Meanwhile, the program, SPSS 25, was used for these statistical analyses.

The highest Pearson's correlation coefficient number belonged to the competitiveness and economic growth variables, at 0.708 (very strong) and close to 1 . On the one hand, the relationship between global innovation and economic growth is characterized by a strong category of 0.402 , or the lowest value among the variables. The probability level for measuring correlation is 0.000 from a standard or condition of 0.05 (5\%).

Descriptions of the study model describe five variables, with global innovation having the largest mean calculated, at 34.5143 , and a standard deviation of 10.78973 . The smallest mean belonged to the human development variable (0.7099), with a standard deviation value of 0.11522 . The research sample or observation was 70 , which is the number of objects and timeframe (Table 3 ).

As shown in Table 4, all of the independent variables had a VIF value under the condition $(n<10)$. That is, the model does not occur in multicollinearity symptoms. The homoscedasticity of the four variables on economic growth has been fulfilled or no heteroscedasticity symptoms occur because the probability is simultaneously smaller than the rule $(n<0.05)$.

The third requirement is the autocorrelation test because this assumption can lead to an unbiased but not efficient multiple regression estimate. The regression results

TABLE 2. Correlations between economic growth (EG), happiness $(H)$, human development (HD), competitiveness (C), and global innovation (GI) tested

\begin{tabular}{|c|c|c|c|c|c|}
\hline Variable & EG & $\mathrm{H}$ & HD & C & I \\
\hline EG & 1.000 & $0.583(0.000)$ & $0.706(0.000)$ & $0.708(0.000)$ & $0.402(0.000)$ \\
\hline $\mathrm{H}$ & $0.583(0.000)$ & 1.000 & $0.868(0.000)$ & $0.789(0.000)$ & $0.870(0.000)$ \\
\hline HD & $0.706(0.000)$ & $0.868(0.000)$ & 1.000 & $0.923(0.000)$ & $0.870(0.000)$ \\
\hline C & $0.708(0.000)$ & $0.789(0.000)$ & $0.923(0.000)$ & 1.000 & $0.758(0.000)$ \\
\hline GI & $0.402(0.000)$ & $0.780(0.000)$ & $0.870(0.000)$ & $0.758(0.000)$ & 1.000 \\
\hline
\end{tabular}
using Pearson's correlation. Significance values in parentheses (significant at $\alpha=0.05$ ). 
TABLE 3. Statistical distribution of economic growth (EG), happiness (H), human development (HD), competitiveness (C), and global innovation (GI).

\begin{tabular}{lccl}
\hline Variable & Mean & Std. deviation & N \\
\hline EG & 5.1927 & 2.45236 & 70 \\
H & 5.3690 & 0.74705 & 70 \\
HD & 0.7099 & 0.11522 & 70 \\
C & 4.5269 & 0.71627 & 70 \\
GI & 34.5143 & 10.78973 & 70 \\
\hline
\end{tabular}

showed that the magnitude was below the provisions $(d u<$ $d<4$ ), or can be said to have no autocorrelation problems. Finally, from the assumption of normality in the study, it was found not to have a probability below $5 \%$, meaning that the residual data from the variables of human development and global innovation were not normal.

Positive intercepts on economic growth are constant, which means that if all the independent variables in the study period increase, a positive and significant influence on economic growth (amounting to $20.40 \%$ ) is found (Table 5). Of the models used, half-human development and global innovation-had a positive and significant effect on economic growth. Happiness had a positive effect, albeit one that was not significant, while competitiveness had a negative effect and was not significant. Simultaneously, human happiness, human development, competitiveness, and global innovation had a positive and significant impact on economic growth in ASEAN during the period of 2013-2019. Overall, the results of the coefficient of determination illustrated the feasibility of this study, as indicated by the $\mathrm{R}^{2}$ value of $68.6 \%$, while $31.4 \%$ stems from a confounding factor or other variable outside the scope of the model.

With respect to year-to-year data, the average index of happiness in ASEAN appeared to fluctuate. The year 2019 was the highest period, with a 5.49 score, whereas the lowest was in 2013, at 5.30 (Figure 2). Of the ten countries, Singapore appeared to dominate during the observations, while the happiness index of Myanmar was the lowest.

A higher level of happiness shows a happier life in ASEAN. Conversely, the lower the index value, the more unhappy the population is indicated to be. Empirical findings suggest there is no significant effect, despite the positive relationship between happiness and economic growth. Talking that into account, hypothesis-1 can be rejected.

TABLE 4. Classic assumption criteria using variance inflation factor (VIF), Glejser, Durbin-Watson (D-W), and Kolmogorov-Smirnov (K-S) methods.

\begin{tabular}{llll}
\hline Assumptions & Method & Test Result & Conclusion \\
\hline Multicollinearity & VIF & $\begin{array}{l}4.109(\mathrm{H}) \\
5.465(\mathrm{HD})\end{array}$ & Assumptions fulfilled. \\
& & $7.186(\mathrm{C})$ & \\
& & $4.398(\mathrm{Gl})$ & \\
& & 0.000 & $\begin{array}{l}\text { Homoscedasticity does } \\
\text { not occur. }\end{array}$ \\
Heteroscedasticity & Glejser & & $\begin{array}{l}\text { Free from } \\
\text { autocorrelation. }\end{array}$ \\
Normality & & 1.659 & $\begin{array}{l}\text { Two variables normally } \\
\text { distributed; two not } \\
\text { n-W }\end{array}$ \\
& K-S & $0.822(\mathrm{H})$ & \\
& & $0.000(\mathrm{HD})$ & normally distributed. \\
& & $0.524(\mathrm{C})$ & \\
& & $0.000(\mathrm{GI})$ & \\
\hline
\end{tabular}

TABLE 5. Hypothesis testing on regression model.

\begin{tabular}{lcccl}
\hline Model & Coefficient & $\mathrm{t}$ & Sig. & Conclusion \\
\hline Constant & 20.404 & 13.731 & 0.000 & Accepted \\
H & 0.104 & 0.226 & 0.822 & Rejected \\
HD & 1.362 & 4.988 & 0.000 & Accepted \\
C & -0.119 & -0.640 & 0.524 & Rejected \\
GI & 0.849 & 5.829 & 0.000 & Accepted \\
\hline
\end{tabular}

Note: $R^{2}=0.686$, Adj. $R^{2}=0.667, F=35.584$, Std. error of estimate $=1.41472$.

Happiness is a measure that describes welfare because it is a reflection of the level of welfare achieved by the population. There were differences between the results of this study and those of Guo and Hu (2011), who found that individual well-being can be predicted and measured, so there is a positive correlation between happiness and economic growth (in the United States, in the case of their study).

Broadly speaking, the human development index in ASEAN has increased in several periods. This is indicated in Figure 3, wherein countries' human development increased, albeit slowly. Singapore led the way among the ten countries studied, while Cambodia was the lowest (one rank below Myanmar).

Human development is the effort of people to live longer, healthier, and have a good level of welfare. It is interpreted as a reflection of their health status, education, and economic capabilities. Hypothesis- 2 was in line with the study analysis, in that an increase in human development will produce positive and significant economic growth in ASEAN. This finding was also in accord with that of Suri et al. (2011), who revealed the power of human development and the important role it plays in determining endogenous economic growth consistently.

There are several reasons why the relationship between competitiveness and economic growth is negative and insignificant, thus rejecting hypothesis-3. This phenomenon is explained by Figure 4, which shows that the competitiveness index in the ASEAN region appeared to increase, but was quite consistent and tended to be below fairly developed countries. Among the countries, Brunei Darussalam ranked first in competitiveness, while the lowest was Myanmar. Over the seven year period, the score was on average lower than 5, even stagnating in some cases. For example, in 2013-2014, the competitiveness in ASEAN was 4.37, yet by 2018-2019 it had not increased beyond the 4.69 level.

Competitiveness is a benchmark of productivity and determines the long-term growth or income of a country.

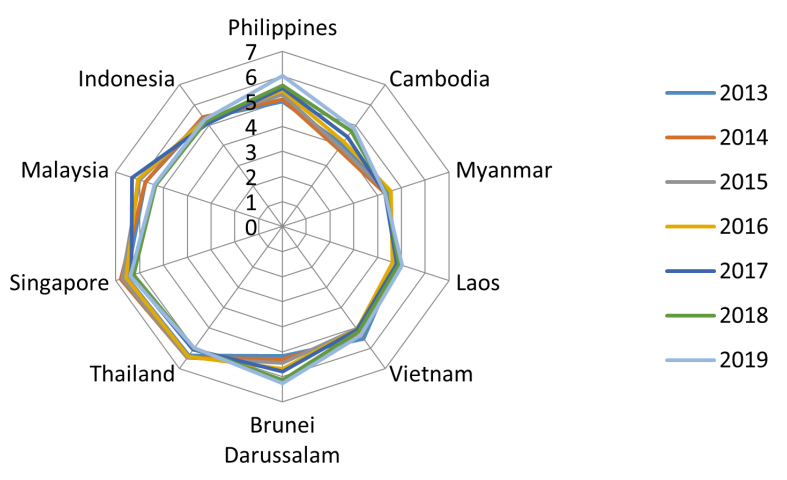

FIGURE 2. Happiness Index in ASEAN, 2013-2019. Data via The Global Economy (2020). 

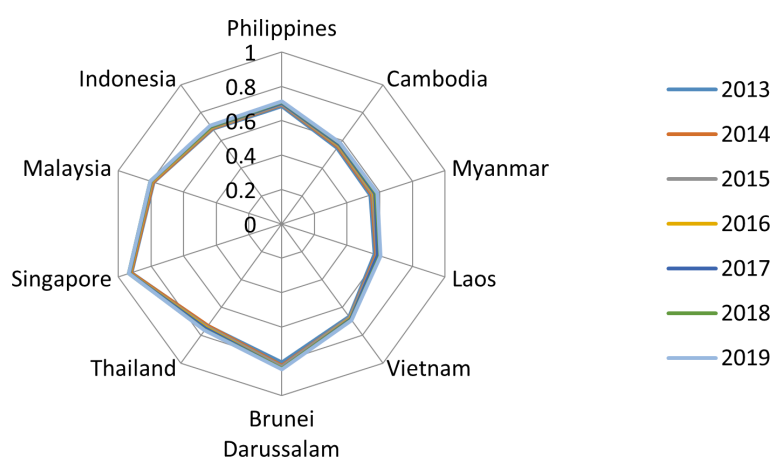

FIGURE 3. Human Development Index in ASEAN, 2013-2019. Data via The Global Economy (2020).

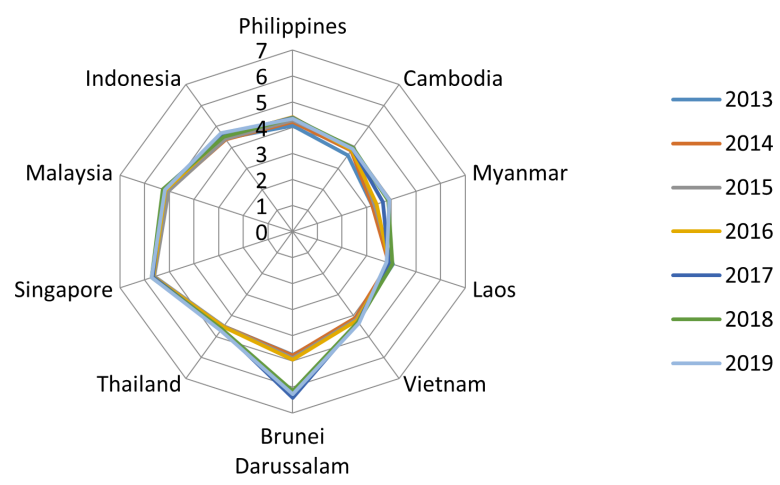

FIGURE 4. Competitiveness Index in ASEAN, 2013-2019. Data via The Global Economy (2020).

For instance, Dadgar et al. (2018) found that there was a positive relationship between competitiveness and economic growth in Iran and selected countries in 2006-2016.

In line with hypothesis-2, there was a positive influence of global innovation and economic growth in ASEAN in the years of 2013-2019. In addition, the global innovation index of ASEAN, which fluctuated even in 2015-2018, dropped and returned to increasing rapidly in 2019 (Figure 5). However, these figures were not a problem if we look at the qualities that have a systematic impact on economic growth, thus enabling hypothesis-4 to be accepted.

In terms of a comparison, Singapore shot sharply upwards as the biggest producer of global innovation compared with the other countries over the seven-year period. Meanwhile, Laos was ranked last in ASEAN, having the lowest score, which rose no higher than 24 (that held by Myanmar in 9th position).

Although innovation has been considered as the main driver of economic growth, nothing has been accepted from the general standard used in its measurement, although in the United States, most innovations contribute to and are related to economic growth. Therefore, our study's findings were in line with what Zhong (2017) previously investigated.

Economic development is absolutely necessary for ASEAN in order to improve the standard of living and welfare of the community through improvements in all fields of activity. Furthermore, to improve welfare, a stable and evenly distributed economic growth is needed.

Countries' economic growth appeared to slow down in 2014-2016, while from 2017 to 2019 there was an increase in inclusion, although it was not very large (Figure 6). Overall, GDP growth for ASEAN in the seven observed years was still relatively low (5.19\%). Brunei Darussalam experi-

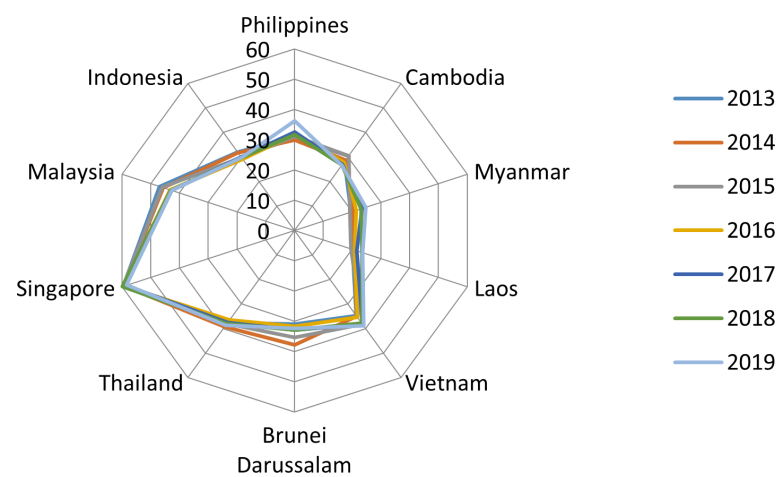

FIGURE 5. Global Innovation Index in ASEAN, 2013-2019. Data via The Global Economy (2020).

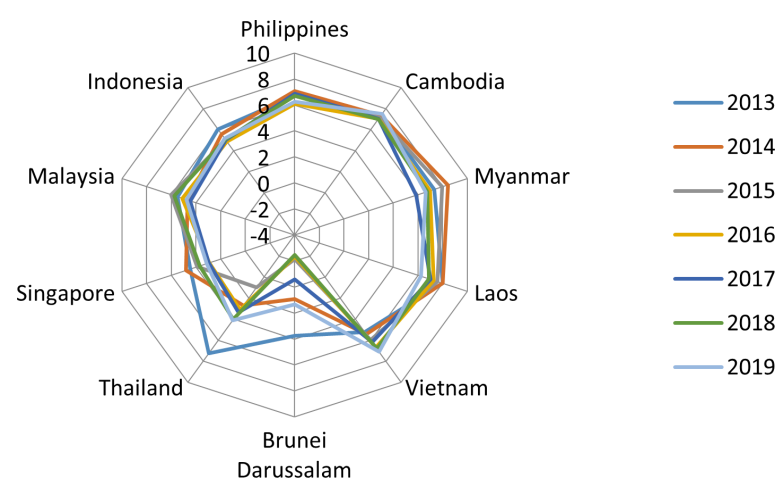

FIGURE 6. Economic growth in ASEAN, 2013-2019. Data via The Global Economy (2020).

enced a recession from negative economic growth, which occurred over four periods, resulting in accumulation at the ASEAN level in the spotlight. On the other hand, even though there was no consistent country, Laos showed the highest growth rate among the studied ASEAN nations.

\section{CONCLUSIONS}

Based on the empirical findings from observations made at the ASEAN level, we found that half of the variables had a positive and significant effect on economic growth, those being human development and global innovation. Conversely, happiness had an insignificant (though positive) impact and competitiveness had a negative and insignificant effect on ASEAN economic growth.

The two-way relationship between human development and global innovation for economic growth needs to be supported by a variety of policies that are very directly in touch with the management of human resources and technology, so that they can be sustainable. The competitiveness and level of happiness of the population can be created, if there is even distribution of income through increased productivity. Furthermore, distributed economic growth will shape better human resources and have an impact on the quality of happiness and competition.

The limitation of our study lies in the time lag, therefore future researchers should consider using a longer period of time. In addition, it is also recommended that other variables are added to allow for more varied analyses or a comparison of the number of samples between regions, particularly ones outside ASEAN. The progress of this study can also be extended by the value of complex origins in other developing countries, so that there are interesting illustrations from time to time. 


\section{ACKNOWLEDGMENTS}

The authors would like to express their gratitude to the reviewers for their truly excellent reviews and comments. We dedicate this work entirely to open access.

\section{AUTHORS' CONTRIBUTIONS}

SZ, SI, DCD, and MA were all involved in the study, from creation of ideas, composition and writing, processing and analyzing data, to final confirmation. All authors read and approved the final version of the manuscript.

\section{COMPETING INTERESTS}

We declare that there is no conflict of interest in the publication of this article.

\section{REFERENCES}

Aghion P, Bloom N, Blundell R, Griffith R, Howitt P. 2002. Competition and innovation: an inverted- $\mathrm{U}$ relationship. Q J Econ. 120(2):701-728. doi:10.1093/qje/120. 2.701.

Al-Zaroog SAM, Baqir AAF. 2020. The impact of global innovation on economic growth in developing countries. J Soc Sci (COES\&RJ-JSS). 9(2):373-393. doi:10.25255/j ss.2020.9.2.373.393.

Appiah M, Amoasi R, Frowne DI. 2019. Human development and its effects on economic growth and development. Int Res J Bus Stud. 12(2):101-109. doi:10.21632/irjbs.

Carlin EA. 1956. Schumpeter's constructed type -the entrepreneur. Kyklos. 9(1):27-43. doi:10.1111/j.1467-6435. 1956.tb02680.x.

Cheung OL. 2014. Impact of innovative environment on economic growth: an examination of state per capita GDP and personal income. J Bus Econ Res. 12(3):257270. doi:10.19030/jber.v12i3.8730.

Costantini V, Monni S. 2008. Environment, human development and economic growth. Ecol Econ. 64(4):867-880. doi:10.1016/j.ecolecon.2007.05.011.

Dadgar Y, Nazari R, Fahimifar F. 2018. The impact of global competitiveness index (GCI) on economic growth in Iran and some selected countries (December 30, 2018). OIDA Int J Sustainable Dev. 11(12):53-60.

Darma DC. 2019. Determinants of the gross regional domestic product of east kalimantan province: Macroeconomic variable review. Rev Integr Bus Econ Res. 9(1):232-241.

Easterlin RA. 2012. Happiness, growth, and public policy. Econ Inq. 51(1):1-15. doi:10.1111/j.1465-7295.2012.00505 .x.

Esmail HAH, Shili NNJ. 2018. The relationship between happiness and economic development in KSA: study of Jazan region. Asian Soc Sci. 14(3):78-87. doi:10.5539/as s.v14n3p78.

Flannelly LT, Flannelly KJ, Jankowski KRB. 2014. Independent, dependent, and other variables in healthcare and chaplaincy research. J Health Care Chaplain. 20(4):161170. doi:10.1080/08854726.2014.959374.

Ghosh M. 2006. Economic growth and human development in indian states. Econ Polit Weekly. 41(30):3321-3329. doi:10.2307/4418499.

Guo T, Hu L. 2011. Economic determinants of happiness: evidence from the US general social survey economic determinants of happiness. https://arxiv.org/ftp/ar xiv/papers /1112/1112.5802.pdf.

Hatzichronoglou T. 1996. Globalisation and competitiveness: relevant indicators. Paris: Organisation for Economic Co-operation and Development Publishing. ht tps://www.oecd.org/officialdocuments/publicdispl aydocumentpdf $/$ ?cote=OCDE/GD\%2896\%2943\&doc Language $=$ En.

Hsiao C. 2005. Why panel data? IEPR Working Paper No. 05.33. doi:10.2139/ssrn.820204.

Kordalska AK, Olczyk M. 2016. Global competitiveness and economic growth: a one-way or two-way relationship? Equilibrium. 11(1):121-142. doi:10.12775/EQUIL.2016.00 6.

Lall S. 2001. Competitiveness indices and developing countries: an economic evaluation of the global competitiveness report. World Dev. 29(9):1501-1525. doi:10.1016/ s0305-750x(01)00051-1.

Loke SP, Khalizani K, Rohati S, Sayaka A. 2014. Drivers and barriers for going green: perceptions from the business practitioners in Malaysia. ASEAN J Sci Technol Dev. 31(2):49-61. doi:10.29037/ajstd.16.

Mukherjee S, Chakraborty D. 2010. Is there any relationship between economic growth and human development? Evidence from Indian states. MPRA Paper No. 22997, Munich. p. 1-27. doi:10.2139/ssrn.1624465.

Pece AM, Simona OEO, Salisteanu F. 2015. Innovation and economic growth: an empirical analysis for CEE countries. Procedia Econ Financ. 26:461-467. doi:10.1016/s2 212-5671(15)00874-6.

Porter M, Sachs J, Warner A. 2000. Executive summary: current competitiveness and growth competitiveness. In: The Global Competitiveness Report 2000. Geneva: The World Economic Forum. p. 14-17.

Ranis G, Stewart F, Ramirez A. 2000. Economic growth and human development. World Dev. 28(2):197-219. doi:10.1 016/S0305-750X(99)00131-X.

Rusu VD, Roman A. 2018. An empirical analysis of factors affecting competitiveness of C.E.E. countries. Econ Res (Ekonomska Istraživanja). 31(1):2044-2059. doi:10.1080/ 1331677X.2018.1480969.

Suri T, Boozer MA, Ranis G, Stewart F. 2011. Paths to success: The relationship between human development and economic growth. World Dev. 39(4):506-522. doi: 10.1016/j.worlddev.2010.08.020.

The Global Economy. 2020. Business and economic data for ASEAN, 2013-2019. http://www.theglobaleconomy.c om/search_site.php?q=ASEAN.

Wierenga B, van Bruggen GH. 1998. The dependent variable in research into the effects of creativity support systems: quality and quantity of ideas. MIS Q. 22(1):8187. doi:10.2307/249679.

Wijaya A, Kasuma J, Tasenţe T, Darma DC. 2021. Labor force and economic growth based on demographic pressures, happiness, and human development. J East Eur Cent Asian Res. 8(1):40-50. doi:10.15549/jeecar.v8i1.571.

Zdaniuk B. 2014. Ordinary least-squares (OLS) model. In: Michalos AC, editor. Encyclopedia of quality of life and well-being research. Dordrecht: Springer Netherlands. p. 4515-4517. doi:10.1007/978-94-007-0753-5_2008.

Zhong L. 2017. Innovation as determinants of economic growth in U.S. counties. J Appl Bus Econ. 19(4):107-116. https://articlegateway.com//index.php/JABE/artic le/view/718/668. 